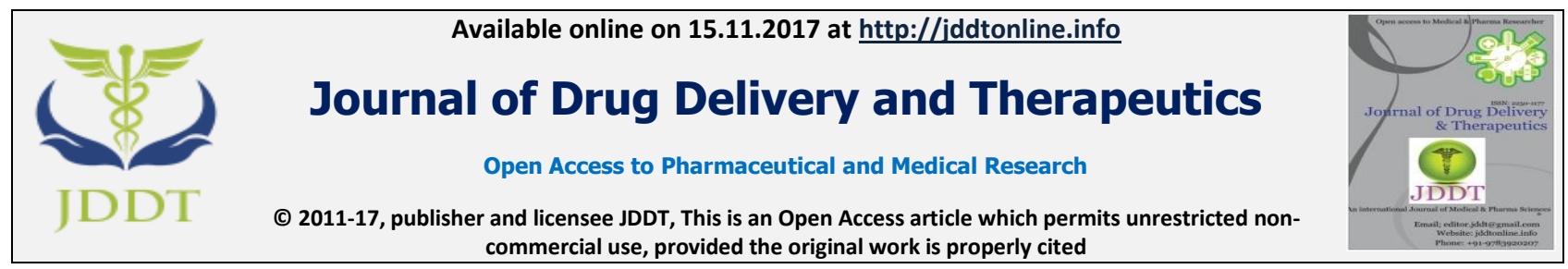

Open $\odot$ Access

Research Article

\title{
Pharmacognostical and Phytochemical evaluation of root of Asparagus racemosus Willd.
}

\author{
Md. Parwez Ahmad*1, Arshad Hussain ${ }^{2}$, Shadma Wahab ${ }^{2}$, Akhtar Alam Ansari ${ }^{1}$, Smita Singh ${ }^{1}$, \\ Chandan Mishra $^{1}$, Shafique Ahmad ${ }^{3}$
}

${ }^{1}$ Department of Pharmacology, National Medical College, Birgunj, Nepal

${ }^{2}$ Faculty of Pharmacy, King Khalid University, KSA

${ }^{3}$ Department of Pharmacology, Faculty of Pharmacy, Hamdard University, New Delhi, India

\section{ABSTRACT}

Aim of this is to examine the Pharmacognastical and Phytochemical properties of Asparagus racemosus. The qualitative microscopy, Phytochemical screening, physicochemical evolution, fluorescence analysis and HPTLC studies were carried out according to the standard procedure recommended in WHO guidelines. The root had compactly arranged, uniseriate, polygonal to radially elongated, thickwalled cell represent the outermost piliferous layer. Immediately laying below the epidermis is extensively developed, several layers of thick cortex made up of parenchymatous cells. The cortical cells contain raphide bundles. The innermost one or two layer of cortex immediately outside the endodermis comprises thick-walled cells, with the numerous oval or circular pits on their walls. Endodermis is composed of a single layer of compactly arranged, barrel-shaped parenchymatous cells. Inner to endodermis is a single layer of thin-walled, parenchymatous cells constituting the pericycle in the form of a ring, which surrounds a central stele. Phytochemical investigation of root shows total ash $(6.5 \% \mathrm{w} / \mathrm{w})$, acid insoluble ash $(1.3 \% \mathrm{w} / \mathrm{w})$, and water-soluble ash $(2.2 \% \mathrm{w} / \mathrm{w})$. Loss on drying is $(5.5 \% \mathrm{w} / \mathrm{w})$. Cold extractive value in pet, ether $(0.5 \% \% \mathrm{w} / \mathrm{w})$ in chloroform $(3.4 \% \mathrm{w} / \mathrm{w})$, methanol $(8.0 \% \mathrm{w} / \mathrm{w})$ and in water $(10.2 \% \mathrm{w} / \mathrm{w})$. Hot extractive value in pet. ether $(0.9 \% \mathrm{w} / \mathrm{w})$, in chloroform $(4.6 \% \mathrm{w} / \mathrm{w})$, methanol $(10.40$ $\% \mathrm{w} / \mathrm{w})$ and in water $(11.2 \% \mathrm{w} / \mathrm{w})$. In methanolic extract and aqueous extract, tannins and saponins present in a major amount. Other constituents include carbohydrate, glycosides and phenolic compounds were present. Various pharmacognistical parameters evaluated in this study help in identification and standardization of the root of Asparagus racemosus.

Keywords: Asparagus racemosus Willd, Satavar; Phytochemical investigation, Phytochemistry

Article Info: Received 03 Sep, 2017; Review Completed 07 Nov, 2017; Accepted 08 Nov, 2017; Available online 15 Nov, 2017

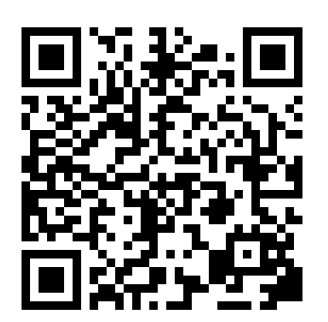

Cite this article as:

Ahmad MP, Hussain A, Wahab S, Ansari AA, Singh S, Mishra C, Ahmad S, Pharmacognostical and Phytochemical evaluation of root of Asparagus racemosus Willd., Journal of Drug Delivery and Therapeutics. $2017 ; 7(6): 76-80$

DOI: http://dx.doi.org/10.22270/jddt.v7i6.1524

*Address for Correspondence

Dr. Md. Parwez Ahmad, Associate Professor, Department of Pharmacology, National Medical College, Brgunj, Nepal. Email: parwezmedicine@gmail.com

\section{INTRODUCTION}

Standardization of natural products is a complex task due to their heterogeneous composition, which is in the form of whole plant, plant parts or extracts obtained thereof to ensure reproducible quality of herbal products, proper control of starting material is utmost essential. The first step towards ensuring quality of starting material is authentication. Thus, in recent years there has been a rapid increase in the standardization of selected medicinal plants of potential therapeutic significance ${ }^{1-2}$.

Since ancient times, plants have been an admonitory source of medicine. Ayurveda and other Indian literature mention the use of plants in treatment of various human diseases. Plants have been the major source of drugs in Indian system of medicine and other ancient systems in the world. Earliest description of curative properties of medicinal plants is found in Rig-Veda, Charaka Samhita 
and Sushrusha Samhita give extensive description on various medicinal herbs. An Informationon medicinal plant in India has been systematically organized ${ }^{3-7}$. India has an ancient heritage of traditional medicine. The materia medica of India provides a great deal of information on the folklore practices and traditional aspects of therapeutically important natural products. Indian traditional medicines based on various systems including Ayurveda, Siddha, Unani and Homeopathy.

The evaluation of these drugs is primarily based on phytochemical, pharmacological and allied approaches including various instrumental techniques such as microscopy, chromatography and others. With the emerging worldwide interest in adopting and studying orthodox systems and exploiting their potential based on different health care systems, the evaluation of the rich inheritance of orthodox medicine is essential.

Asparagus racemosus Willd.is an important medicinal plant of tropical and subtropical India. Its medicinal usage has been reported in the Indian and British Pharmacopoeias and in indigenous systems of medicine. The genus Asparagus includes about 300 species around the world. The genus is considered to be medicinally important because of the presence of steroidal saponins and sapogenins in various parts of the plant. Out of the 22 species of Asparagus recorded in India; Asparagus racemosus is the one most commonly used in traditional medicine ${ }^{8-9}$.

Therefore, the aim of this paper is to present an overview of traditional, pharmacognostical, phytochemical investigations carried out on the roots of plant Asparagus recemosus Willd.

\section{MATERIALS AND METHODS}

\section{Collection and identification}

For identification and Taxonomic authentication, samples of plant material were given to National Botanical Research Institute (NBRI) Lucknow, India. The text report from National botanical research institute, Lucknow, confirmed the authenticity of plant materials, NBRI-SOP-202 \& CIF-RB-2-129, 28-062011 voucher specimen no \& Receipt no. and date respectively, The roots were collected, washed with water, dried in sunlight and stored properly. The dried roots was powdered and passed through the sieve no. 60 . Coarse powder was used for phytochemical work.

\section{Morphological studies}

The morphological characters like condition, type, size, shape, colour, odour and taste of Asparagus racemosus Willd. roots were studied ${ }^{10}$.

\section{Microscopical studies}

The sufficient quantity of Asparagus racemosus Willd. roots were sectioned with the help of fresh blade. The sect ions were first cleared with chloral hydrate and then stained with Phloroglucinol and concentrated HCL. Sections were also stained with Iodine solution (I-KI) for starch.

\section{Physicochemical constants}

Ash values were used to determine the quality and purity of the crude drugs. Procedure given in Indian Pharmacopoeia was used to determine the different ash values such as total ash and acid insoluble ash. Cold and extractive values were also determined as per procedure given in Indian Pharmacopoeia ${ }^{11}$.

\section{Phytochemical analysis}

The dried powder material was extracted with methanol and water successively in a soxhlet apparatus. The extracts were filtered while hot and concentrated under reduced pressure. The practical and \% yields of the extracts were calculated. The concentrated methanolic and aqueous extracts of the roots were subjected to qualitative chemical test for the identification of various active constituents ${ }^{12-15}$.

\section{Determination of total flavanoid content}

$10 \mathrm{mg} / \mathrm{ml}$ solution of drug was prepared in methanol. $0.5 \mathrm{ml}$ of solution was taken and added $1.5 \mathrm{ml}$ methanol. To this added $0.1 \mathrm{ml}$ of $\mathrm{AlCl}_{3}$ and $0.1 \mathrm{ml}$ of $\mathrm{CH}_{3} \mathrm{COONa}$ reagents and added $2.8 \mathrm{ml}$ Distilled water and kept for 30 minutes. After that absorbance was taken at $415 \mathrm{~nm}$ and for standard, $0.5 \mathrm{ml}$ of standard dilution of quercetin was taken and added $1.5 \mathrm{ml}$ methanol. To this added $0.1 \mathrm{ml}$ of $\mathrm{AlCl}_{3}$ and $0.1 \mathrm{ml}$ of $\mathrm{CH}_{3} \mathrm{COONa}$ reagents followed by $2.8 \mathrm{ml}$ Distilled water and kept for 30 minutes after that absorbance was taken at $415 \mathrm{~nm}$. Flavonoidal contents in drug were calculated by using standard calibration curve ${ }^{16}$.

\section{Determination of total phenolic content}

$10 \%$ F.C. reagent in distilled water, $\mathrm{Na}_{2} \mathrm{CO}_{3}(1 \mathrm{M})$ in distilled water and Standard (Gallic acid) $1 \mathrm{mg} / \mathrm{ml}$ solution in methanol was prepared. Different dilutions of standard gallic acid $(25 \mu \mathrm{g} / \mathrm{ml}$ to $300 \mu \mathrm{g} / \mathrm{ml})$ was made in methanol. Samples were prepared $10 \mathrm{mg} / \mathrm{ml}$ solution of drug in methanol followed by addition of $5 \mathrm{ml} \mathrm{F.C.} \mathrm{reagent} \mathrm{and} 4 \mathrm{ml} \mathrm{Na} \mathrm{CO}_{3}$ solution. Absorbance was taken at $765 \mathrm{~nm}$ after 15 minutes.Phenolic contents in drug was calculated by using standard calibration ${ }^{17}$.

\section{High Performance Thin Layer Chromatography (HPTLC)}

High performance thin layer chromatography is very useful in analysis of phytopharmaceuticals as it combines the art of chromatography with quickness. HPTLC is a major advancement of TLC principle requiring shorter time and better resolution. Silica gel of very fine particle size is widely used as sorbent in HPTLC. The use of smaller particle size helps in greater resolution and sensitivity. Sample preparation in HPTLC needs a high concentrated solution, as very less amount of sample is needed for application. The analytical profiles for carotenoids, tropane alkaloids, flavanoids, steroidal compounds, anthracene aglycones, lipids etc, have been developed by using this technique. Now a day, it is applied to obtain "finger-print" patterns of herbal formulations, quantification of active ingredients and also detection of adulteration.

In the last two decades (HPTLC) has emerged as an important tool for the qualitative semi-quantitative and 
quantitative phytochemical analysis of herbal drugs and formulations. This includes developing TLC fingerprint profiles and estimation of chemical markers and biomarkers. The major advantage of HPTLC is that several samples can be analyzed simultaneously using a small quantity of mobile phase.

\section{Steps involved in HPTLC}

\section{Selection of chromatographic layer}

Pre-coated silica gel plate 60 F 254 (Merck), were selected for the chromatographic separation.

\section{Sample preparation}

Sample was prepared by re-dissolving a small quantity of methanol residue in methanol.

\section{Application of the sample}

Sample was applied on pre-coated plate with the help of CAMAG LANOMAT-V sample applicator.

\section{Chromatographic development}

A twin trough chamber was used for the development of chromatogram. The chamber was allowed to saturate with solvent system before use. Then pre coated plate was dipped in saturated chromatographic chamber containing the solvent system and was allowed to elute up to few $\mathrm{cm}$. Plate was air dried after resolution. The experiment was carried out at room temperature in diffused day light.

\section{Detection of the spots}

Spots on the plate were detected with the help of U.V.

\section{Scanning}

CAMAG TLC Scanner 3 was used for scanning the HPTLC plate and scan was done at $366 \mathrm{~nm}$ wavelength.

\section{Documentation of chromatoplates}

Documentation of chromatoplates was done with the help of computer and simultaneously photograph of HPTLC was taken.

\section{RESULTS AND DISCUSSION}

\section{Morphological characters ${ }^{10}$}

The roots of Asparagus racemosus Willd. are perennial, fascicled, succulent, tuberous fairly smooth, color varies from creamish white to light yellow, illustrated in fig 1 .

\section{Microscopic characters}

The fixed, sectioned and stained plant materials as well as powder and macerated materials were studied using light microscope according to the usual microscopic techniques. The results of microscopic feature of Asparagus racemosus Willd. were systematically described and illustrated. The root had compactly arranged,uniseriate,polygonal to redialy elongated, thick walled cell represent the outermost piliferous layer. Immediately laying below the epidermis is extensively developed, several layer of thick cortex made up of parenchymatous cells. The cortical cells contain raphide bundles. The innermost one or two layer of cortex immediately outside the endodermis comprises thick walled cells, with the numerous oval or circular pits on their walls. Endodermis is composed of a single layer of compactely arranged, barrel-shaped parenchymatous cells. Inner to endodermis is a single layer of thin walled, parenchymatous cells constituting the pericycle in the form of ring, which surrounds a central stele. Phloem and xylem groups many in number, are arranged on alternate radii and form of a ring. Vessel elements possess spiral, scalariform and pitted thickening.

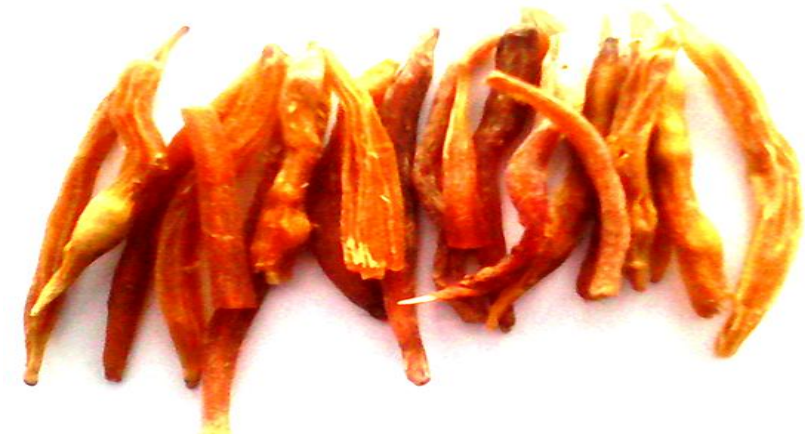

Figure 1: Root of Asparagus racemosus Willd.

\section{Powder microscopy}

Powdered sample of Asparagus racemosus Willd. was examined for their organoleptic properties. Microscopical evaluation of powder of roots of Asparagus recemosus Willd. shows different characters. Powder sample is creamish yellow, acicular raphides, starch grain sand vessels elements with scalariform thickenings.

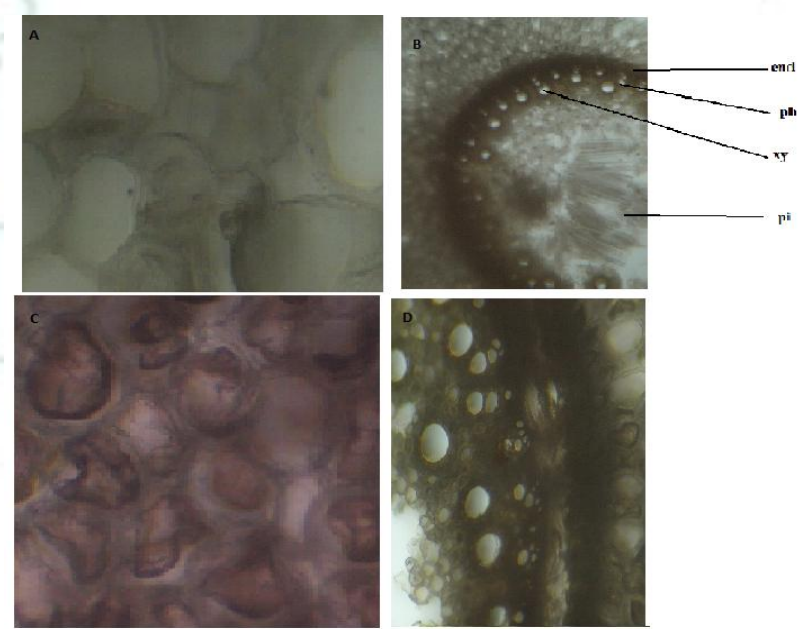

Figure 2: TS of root of A. racemosus, A-TS showing part of outer cortex at higher magnification, B-TS showing part of vascular ring, C-part of inner cortex at higher magnifications, D-showing part of vascular ring at higher magnification.

\section{Physicochemical parameters}

Phytochemical investigation of root shows, - total ash $(8.2 \% \mathrm{w} / \mathrm{w})$, acid insoluble ash $(2.94 \% \mathrm{w} / \mathrm{w})$, and water soluble ash $(5.6 \% \mathrm{w} / \mathrm{w})$. Loss on drying is $(5.53 \%$ $\mathrm{w} / \mathrm{w})$. Cold extractive value in pet, ether $(0.5 \% \mathrm{w} / \mathrm{w})$ in chloroform $(3.41 \% \mathrm{w} / \mathrm{w})$, in methanol $(8.04 \% \mathrm{w} / \mathrm{w})$ and in water $(10.2 \% \mathrm{w} / \mathrm{w})$. Hot extractive value in pet, ether $(0.9 \% \mathrm{w} / \mathrm{w})$, in chloroform $(4.6 \% \mathrm{w} / \mathrm{w})$, methanol 
$(10.40 \% \mathrm{w} / \mathrm{w})$ and in water $(10.6 \% \mathrm{w} / \mathrm{w})$. Other constituents include carbohydrate, glycosides and phenolic were present determined by different phytochemical test of glycosides (Fehling's test), tannins $\left(5 \% \mathrm{FeCl}_{3}\right.$ solution).

Shinoda test (Magnesium Hydrochloride reduction test) for flavanoids: To the extract or fraction, added few fragments of Magnesium ribbon and added cone. Hydrochloric acid drop wise, pink scarlet, crimson red or occasionally green to blue color appears indicated presence of flavanoids.
Carbohydrates: Extracts were dissolved individually in $5 \mathrm{ml}$ of distilled water and filtered. The filtrates were used to test the presence of carbohydrates.

\section{Fluorescence analysis}

The fluorescence analysis is one of the important parameters for the assessment of purity and quality of selected plant materials. The powder drug was treated with different solvents and was examined under UV light.

Table 1: Fluorescence analysis of root of A. racemosus

\begin{tabular}{|l|l|l|l|l|}
\hline \multirow{2}{*}{ Chemical Treatment } & Observation & \multicolumn{2}{|l|}{} \\
\cline { 2 - 4 } & Day Light & UV 254nm & UV 366nm \\
\cline { 2 - 4 } Drug powder as such & Yellowish brown & Light Brown & Gray white \\
\hline Conc. $\mathrm{H}_{2} \mathrm{SO}_{4}$ & Brown & Dark green & Black \\
\hline Conc. $\mathrm{H}_{2} \mathrm{SO}_{4}+$ Distilled Water & Light cream & Dark green & Black \\
\hline Conc. $\mathrm{HCl}$ & Dark red & Light red & Reddish \\
\hline Conc. $\mathrm{HCl}+$ Distilled Water & Light Brown & Dark green & Black \\
\hline Conc. $\mathrm{HNO}_{3}$ & Dark Brown & Dark green & Brown \\
\hline Conc. $\mathrm{HNO}_{3}+$ Distilled Water & Light Brown & Dark green & Brown \\
\hline Methanol & Light Brown & Brown & Brown \\
\hline Chloroform & Light brown & Black & Black \\
\hline Petroleum ether & Light brown & Dark green & Black \\
\hline FeCl & Black & Black & Black \\
\hline Picric acid & Light grey & Grey & Yellowish brown \\
\hline Sodium Hydroxide $\mathrm{H}$ & Brown & Dark green & Brownish green \\
\hline Iodine & Dark brown & Dark green & Black \\
\hline Distilled Water & Brown & Dark green & Black \\
\hline
\end{tabular}

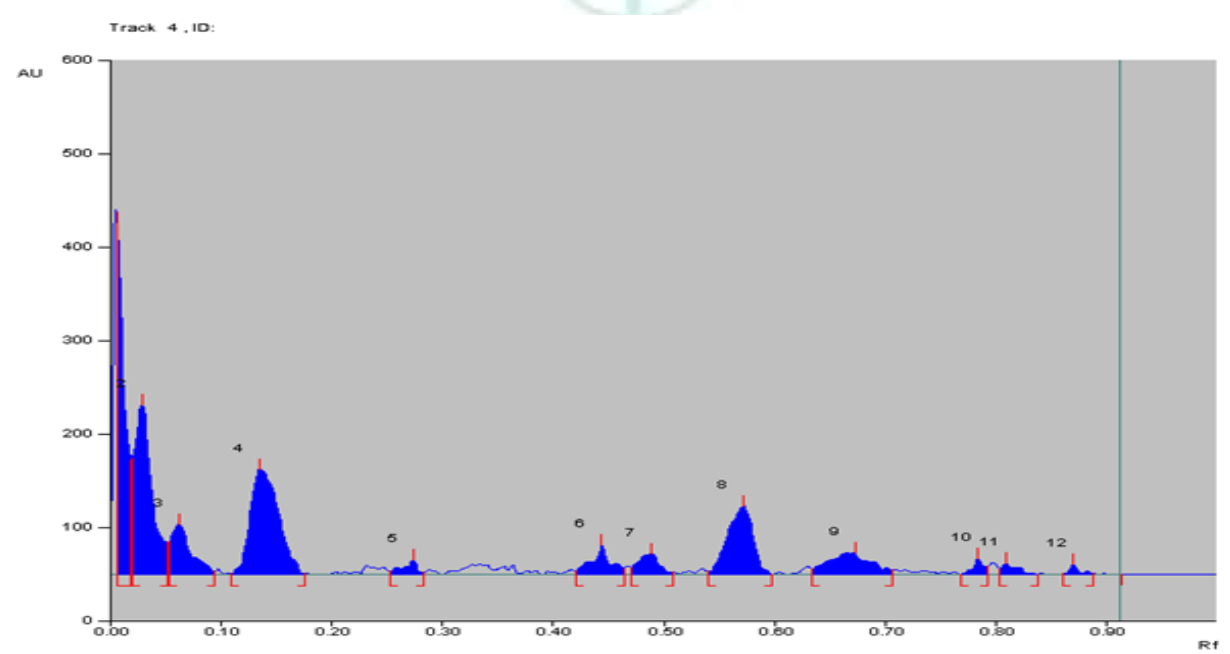

Figure 3: HPTLC profile of methanolic extract of Asparagus racemosus

\section{Total Flavanoid and Phenolic content}

The qualitative phytochemical screening expose to presence of flavanoid and phenolic content. Total flavanoid content Asparagus racemosus 51.84 \pm 0.089 $\mu \mathrm{g} / \mathrm{ml}$ equivalents to quercetin and total phenolic content were Asparagus racemosus $60.30 \pm .076 \mu \mathrm{g} / \mathrm{ml}$. equivalents to gallic acid were present.

\section{HPTLC of methanolic extract}

The results from HPTLC finger print scanned at wavelength $200 \mathrm{~nm}$ for methanolic extract of Asparagus racemosus root powder There are twelve polyvalent phytoconstituents and Component number 2 at $R_{f} \quad 0.02$ showed maximum concentration.

Asparagus racemosus Willd. roots are frequently used as a herbal remedy for an align of human disorders including used in Ayurveda for the treatment of various diseases. The main active constituents of Asparagus racemosus Willd. are steroidal saponins (Shatavarins IIV) that are present in the roots. Shatavarin IV is a glycoside of sarsasapogenin having two molecules of rhamnose and one molecule of glucose ${ }^{18}$. 
To make certain reproducible value of herbal medicines suitable control of preliminary material is almost necessary. The primary step towards ensuring feature of starting material is authentification followed by creating statistical values of principles for evaluation. Pharmacognostical parameter for easy identification like root constituents, microscopy and physicochemical analyses are few of the basic procedure for standardisation of natural sources of drugs ${ }^{19}$. As a part of standardization, the macroscopical examination of A. racemosus was studied. It showed important characteristics. It is a technique of qualitative evaluation which is settled on the study of morphological and receptive interprets of drugs (Figure 1) The anatomy of root (Figure 2) and was examined by taking transverse sections. The microscopical analysis of the transverse section was the recognizing features and can be utilized as anatomical marker. It revealed the histological features of the drug.

The total ash value, extractive value will be helpful in identification and authentification of the plant material. The pharmacognostical and phytochemical evaluation of Asparagus racemosus can provide useful information for the identification and authentification of the plant. The results of the phytochemical investigation of various solvent extracts revealed the presence of various secondary metabolites with varied degree. Recent reports of antibacterial, anti-diabetic, antioxidant, antiulcerogenic, anti-amnesic, antitussive, hepatoprotective and immunomodulatory activities of flavonoids have generated interest in studies of flavonoid containing plants ${ }^{9}$, and these flavonoids are known as nature's caring drug which possesses numerous biological and pharmacological activities. Phenolic compounds are widely distributed in the plant kingdom and have been

\section{REFERENCES}

1. Reddy YSR, Venkatesh S, Ravichandran T, Subbaraju T, Suresh B. Pharmacognostical studies of Wrightia tinctoria bark. Pharma Biol. 1999; 37: 291-295.

2. Venkatesh S, Madhava RB, Suresh B, Swamy MM, Ramesh M. Pharmacognostical identification of Rumex nepallensis Spreng (Polygonanceae)- an adulterant for Indian Rhubarb. Nat Prod Sci. 2004; 10:43-47.

3. Kirtikar KR and Basu BD.(Book) Indian medicinal plants (India), 2nd ed., Vol. 2, India press publisher, Allahabad, India. 1989, 2389.

4. Rastogi Ram P, Malhotra BN. Indian medicinal plants. Central Drug Research Institute, Lucknow, Council for Scientific and Industrial Research, New Delhi, 1989; 4:189-192.

5. Satyavati GV, Raina MK, Sharma M. Medicinal Plants of India. Indian council of Medical Research, New Delhi. 1976, Vol. IV, 123-125.

6. Satyavati GV, Gupta AK. Medicinal Plants of India. Indian Council of Medical Research, New Delhi. 1987, Vol. II. 12751280.

7. Husain A, Virmani OP, Popli SP, Misra LN, Gupta MM,Srivastava GN. Dictionary of Indian Medicinal Plants. Lucknow, India, CIMAP, 1992, 546.

8. Goyal RK, Singh J, Lal H. Asparagus racemosus - an update. Ind J Med Sci. 2003; 57:408-414.

9. Hussain A, Ahmad MP, Wahab S, Hussain MS, Ali M. A Review on Pharmacological and Phytochemical Profile of reported to have several biological activities including antioxidant properties. Earlier reports discovered that root of Asparagus racemosus extracts, especially Saponins possess abundant biological properties which include anti-diabetic, antioxidant, anti-ulcerogenic, antiamnesic, antitussive, hepatoprotective effects 9 . Steroids are believed to be a biosynthetic precursor for cardenolides in plants. Recently, a number of studies have been reported on the phytochemistry of Aasparagus raecmosus across the world. The presence of secondary metabolites which include alkaloids, flavonoids, polyphenols, steroids and saponins in the crude extracts of Aasparagus raecmosus suggest that Asparagus racemosus can be used as antibacterial, anti-diabetic, antioxidant, anti-ulcerogenic, anti-amnesic, antitussive, hepatoprotective and immunomodulatory agents, have immeasurable medicinal value and have been comprehensively used in the drug and pharmaceutical industry.

\section{CONCLUSIONS}

In these present investigations, various pharmacognostical standardization parameters such as macroscopy, microscopy, and preliminary phytochemical screening were carried out which could be helpful in authentification of Asparagus racemosus Willd. The result of the present study will also serve as reference material in the preparation of herbal monograph.

Conflict of interest statement: The authors have no conflict of interest.

Acknowledgement: We are grateful to Vice Chancellor Prof. S. W. Akhtar, Integral University, Lucknow, India for provide Lab. facilities for this research work.

Asparagus racemosus Willd. Pharmacologyonline. 2011; 3:13531364.

10. Wallis TE. Text book of Pharmacognosy, CBS Publisher and Distributors, 2001, 68-78.

11. Indian Pharmacopoeia, Ministry of Health and Family Welfare, Government of India, Controller of Publication, 1985; 310.

12. Harbone JB. Phytochemical Method, Chapman Hall, 1988, 117 119.

13. Mohammed A. Text Book of Pharmacognosy, CBS Publishers and Distributors, 1994; 81, 116, 372, 447.

14. Agrawal OP. Advanced practical organic chemistry, Goel Publishing House, 2000, 43-59.

15. Divakar MC. Plant Drug Evaluation, CD Remedies Publication, 2002; 49-52, 84-89.

16. Chang C, Yang M, Wen H, Chern J. Estimation of total flavonoid content in propolis by two complementary colorimetric methods. J Food Drug Anal. 2002; 10:178-182.

17. Singleton V L, Orthofer R, Lamuela-Raventos R M. Analysis of total phenols and other oxidation substrates and antioxidants by means of Folin-Ciocalteau reagent. Meth Enzymol. 1999; 299:152-178.

18. Joshi J, Sukh Dev. Chemistry of Ayurvedic crude drugs: part VIII: Shatavari-2: Structure elucidation of bioactive Shatavarin-I and other glycosides. Ind J Chem. 1988; 27B:12-16.

19. Dinakaran SK, Banji D, Godala P, Harani A. Pharmacognostical evaluation study on Crotalaria juncea Linn. American-Eurasian J Sci Res. 2011; 6(3):139-145. 